\title{
521 鋼/アルミニウム合金のレーザ接合における界面制御
}

\author{
Interface Controlling on Laser Welding of Steel / Aluminum Alloy \\ O正 管下 幸雄 (長岡技科大) \\ 正 武藤 睦治 (長岡技科大) \\ 正 許 金泉 (上海交通大学) \\ 奥村 勇人（長岡技科大）
}

\begin{abstract}
Yukio MIYASHITA, Nagaoka University of Technology, Nagaoka, 940-2188 Japan
Yoshiharu MUTOH, Nagaoka University of Technology

Jin-Quan XU, Shanghai Jiao Tong University, China

Hayato OKUMURA, Nagaoka University of Technology
\end{abstract}

Key Word: Laser welding, Dissimilar metals joint, Steel, Aluminum alloy, BEM analysis

\section{1. 緒言}

異なる材料を組合せて構成する“ハイブリッド構造”は，自 動車車体の軽量化に有効であり，排出ガス削減や燃費向上が期 街される ${ }^{11}$ ．そのためには，信頼性のある異材接合技術が不可 欠である。著者らは，これまでに，通常の溶融溶接を行うと， 界面に脆㤘な金属間化合物を生成するために，強度が著しく低 下する，鋼とアルミニウム命金の材料組命せを取上げ，境界要 素熟仁導解析によって溶接条件を求めることで，接命体を作製 する乎法を小した ${ }^{2)}$ 。この手法では，Fig.1に示すように，画 材料の，泬融温度の違いを利用し，界面において，固相／液相反 志を扣じさる。本研究では，得られた接合体について強度試 験捛よひ破面・断面観察を行い，界面の状態を調べ，さらに， 接触片により界面状態を制御する手法について検討した。

\section{2. 試酷方法}

材料組せは，鋼（SPCC）／アルミニウム合全（A5052-0）とし た。供武材の化学成分および機械的性質を Table 1 および2に 示す。試験片は，100×40m，曆さ $1 \mathrm{~mm}$ の板材を使用した。レ

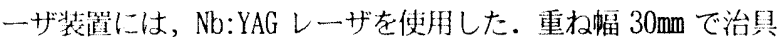
に取价け，SPCC 側からレーザを照射することで重ね接合を行 った。得られた接合体をゲージ部幅 $14 \mathrm{~mm} の$ の形状に加工し，引張 りーせん断試験を行った。なお，本研究で示すすべての試験に おいて,試験片表面からのデフォ一カス距離を上方へ $20 \mathrm{~mm}$ とし， シールドガスには流量 401/minの Ar ガスを用いた。

\section{3. 結果およひ考察}

3.1 接合条件と接合体強度 接合条件をFig.2 に示す，同図中 の矢目は，BEM 解析より推測した接合条件を示しており，寒験 結果とよく…致している. 例として，レーザ出力 $2.5 \mathrm{~kW} て ゙$ 得ら れた接命体の破断荷重と溶接速度の関係を Fig.3に示す.なお， 重ね接命体の引偯り一せん断試験において，未接合部は幾何学 的にき裂と同義であるため, 本報告では, 破断荷重で接合体強 度を整理した.Fig.3 より, 阔出力で比較すると, 溶接速度が 低い条作で作製した接合体の方が，高い破断荷重を示した。な お，レーザ出力 $2.5 \mathrm{~kW}$ ，溶接速度 $0.6 \mathrm{~m} / \mathrm{min}$ で得られた接合体が 本研究では最大破断荷重を示し, 母材 (A5052) 引張り強度から 求められる破断侕重の約 73\%であった。



Fig. 1 Schematic illustration of the laser lap joint.
Table 1 Chemical compositions for the materials used.

\begin{tabular}{|c|c|c|c|c|c|c|}
\hline Material & $\mathrm{Al}$ & $\mathrm{Si}$ & $\mathrm{Fe}$ & $\mathrm{Cu}$ & $\mathrm{Mn}$ & $\mathrm{Mg}$ \\
\hline A5052-O & bal. & $<0.25$ & $<0.40$ & $<0.10$ & $<0.10$ & $2.2 \sim 2.8$ \\
\hline SPCC & - & - & bal. & - & $<0.50$ & - \\
\hline Material & $\mathrm{Cr}$ & $\mathrm{Zn}$ & $\mathrm{Ti}$ & $\mathrm{C}$ & $\mathrm{P}$ & $\mathrm{S}$ \\
\hline A5052-0 & $.15 \sim 0.3$ & $<0.10$ & - & - & - & - \\
\hline SPCC & $<0.50$ & - & $<0.12$ & $<0.12$ & $<0.04$ & $<0.045$ \\
\hline
\end{tabular}

Table 2 Mechanical properties for the materials used.

\begin{tabular}{|c|c|c|c|c|c|}
\hline Material & $\begin{array}{c}\text { Tensile } \\
\text { strength } \\
(\mathrm{MPa})\end{array}$ & $\begin{array}{c}\text { Elongation } \\
(\mathbf{(})\end{array}$ & $\begin{array}{c}\text { Shear } \\
\text { strength } \\
(\mathrm{MPa})\end{array}$ & $\begin{array}{c}\text { Young' s } \\
\text { modulus } \\
(\mathrm{GPa})\end{array}$ & $\begin{array}{c}\text { Thermal } \\
\text { conductivity } \\
\left(\mathbf{W} / \mathrm{m} \cdot{ }^{\circ} \mathrm{C}\right)\end{array}$ \\
\hline A5052-0 & 195 & 27 & 125 & 70 & 137.0 \\
\hline SPCC & $>280$ & $>36$ & - & - & 67.4 \\
\hline
\end{tabular}

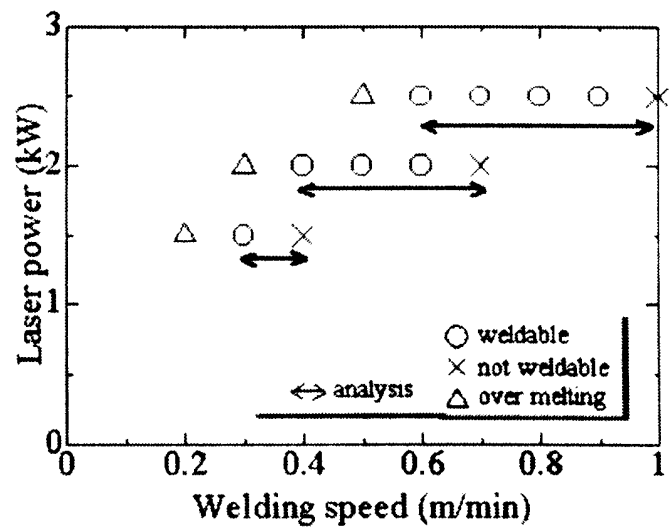

Fig. 2 Weldability of SPCC/A5052 joint.



Fig. 3 Relationship between failure load and welding speed at laser power of $2.5 \mathrm{~kW}$. 


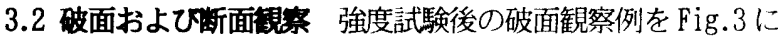
小す．接合体の破面上には，多くのボアが認められた．また， 同じレーザ出っで比較すると，溶接速度の増加にともない，ポ アの、法が大きくなり，中央部に集合する傾向を示した．接合 メカニズムが異なるため,そのまま比較することはできないが， これはアルミニウム合金のレーザ溶接において報告されている 傾问と類似している ${ }^{3)}$. 接合体断面観察例を Fig.4に示す。同 汹より，接合体界面には，金属間化合物層が認められたが，そ の厚さは不均一であり,場所によっては末接命部も観察された。 しかし，同じレ一ザ出力で比較すると，浴接速度が低いほど， すなわち，入熱が大きいほど金属間化合物層の厚さは增加する 傾问を示した。

3.3 接触片の影 Fig.5 に模式的に示すように,レーザ照射 部直下のアルミニウム合金側から接触片を押当てた状態で接合 '奏騃を行った。本研究では，半円柱形の S45C 製ブロックを用い た。押付け荷重は，ひずみゲージにより測定し，ネジにより調 整した. なお，本研究では，押付け荷重は $98 \mathrm{~N}$ ，レーザ出力は $2.5 \mathrm{~kW}$ で一定とした。レーザ溶接実験より，接触片を用いた場 分にも，用いない場合と同様の溶接速度 0.6 0.9 m/min の範囲 で接合体が得られた。なお，溶接中，接触片入熱が伝わるため， 接触片の形状や材質を変えることによって，溶接条件が変化す ることを，別の奏験で確認している。本実験では，接触版
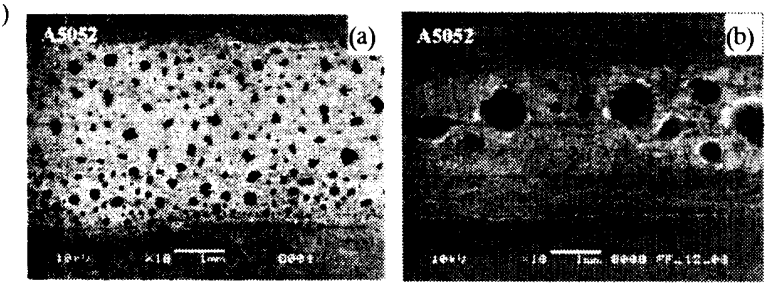

Fig. 3 Fracture surfaces of A5052 side for the specimens welded with laser power of $2.5 \mathrm{~kW}$ at welding speed of (a) $06 \mathrm{~m} / \mathrm{min}$ and (b) $0.8 \mathrm{~m} / \mathrm{min}$.

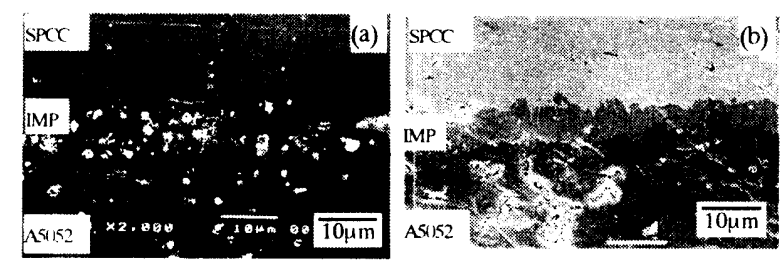

Fig. 4 Cross sectional observations for the specimens welded with laser power of $2.5 \mathrm{~kW}$ at welding speed of (a) $0.6 \mathrm{~m} / \mathrm{min}$ and (b) $0.8 \mathrm{~m} / \mathrm{min}$.

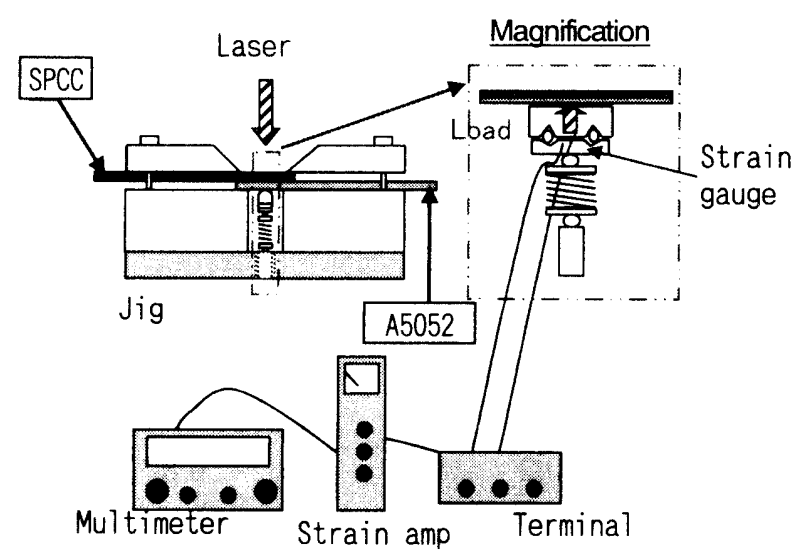

Fig. 5 Apparatus for applying bonding load.
状が半円柱形であるため, 線接触となり, 本実験の範囲内では， 溶接条件に顕著な影響が認められなかったものと考えられる。 引張り一せん断試験の結果, 接触片を用いた場合の最大破断荷 重は，月材破断荷重の約 $81 \%$ あ゙り，接触片を用いない場命と 比較して向上した．接合体の破面観察例をFig.6に正す，阔为 より，接触少を用いない場合に認められた大きなポつは観祭さ れなかった。これは，接触片により，A5052 側に生じたポアか 接合部の外一押出されたためと考えられる.接合体の断面観察 例をFig.7に示す．同図より，接触片が無い場命と比較して， 接触片を用いた場合には，界面に生成される金閩間化合物層の 厚さが比較的均一となっている. Fig.7 のような断面観察より 求めた，金属間化合物層の厚さと溶接速度の関係をFig.8に示 す.同図より，接触片により密着状態を向上させた場合には,入 熱量で金属間化合物の生成状態をコントロールできると考えら れる.

\section{結言，参考文献；省略.}

謝辞本研究は, 新エネルギー・産業技術総合開発機構 （NED0）産業技術研究助成事業による支援を受けた．また，本 研究の一部は，(粆レーザ㐫用工学研究所マルチクライアントフ ロジェクトおよび文部科学省 21 世紀COE プログラムに関連して 行われた. 関係备位に深く感謝の意を表する.

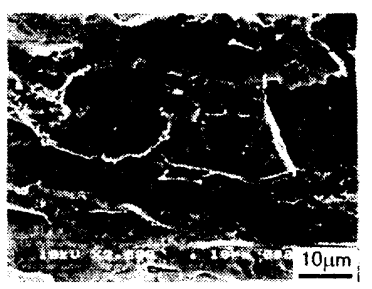

Fig. 6 Fracture surfaces of A5052 side for the specimen welded with laser power of $2.5 \mathrm{~kW}$, applying bonding load of $98 \mathrm{~N}$ and welding speed of $0.6 \mathrm{~m} / \mathrm{min}$.

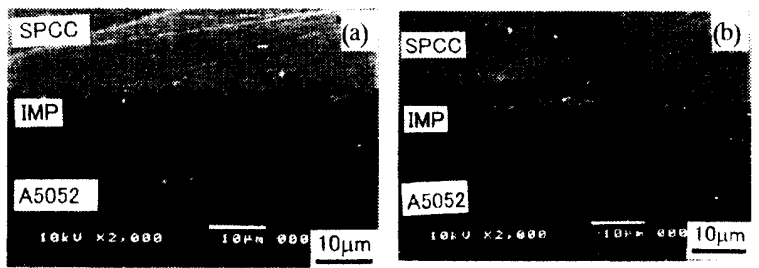

Fig. 7 Crass sectional observations of the specimen welded with laser power of $2.5 \mathrm{~kW}$, applying bonding load of $98 \mathrm{~N}$ and welding speed of (a) 0.6 , (b) $0.8 \mathrm{~m} / \mathrm{min}$.

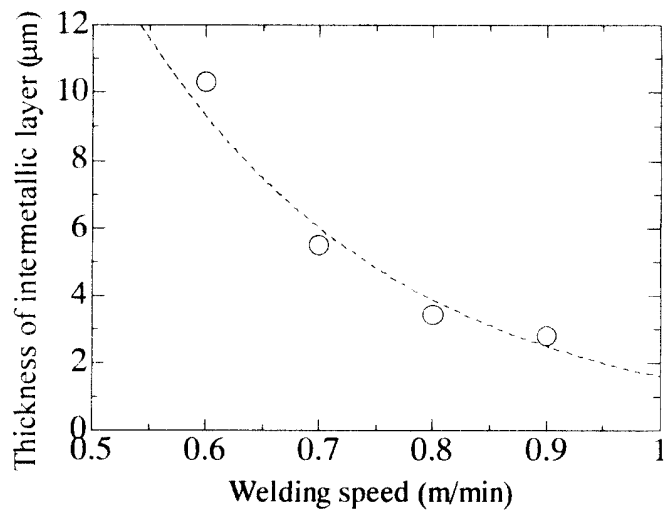

Fig.8 Relationship between thickness of intermetallic layer and welding speed (Laser power; $2.5 \mathrm{~kW}$, Lapping width; $30 \mathrm{~mm}$, defocus; $+20 \mathrm{~mm}$, Bonding load; $98 \mathrm{~N}$ ) 